\title{
Adding Value to the Meat of Spent Laying Hens Manufacturing Sausages with a Healthy Appeal
}

-Author(s)

Souza KMR de

Araujo RB ${ }^{2}$

Santos $\mathrm{AL} \mathrm{dos}^{3}$

Rodrigues CEC

Faria DE de ${ }^{5}$

Trindade $\mathrm{MA}^{6}$

PhD. student in Animal Science. School of Animal Science and Food Engineering. Universidade de São Paulo, Pirassununga, São Paulo, Brazil.

2 MSc. student in Animal Science. School of Animal Science and Food Engineering. Universidade de São Paulo, Pirassununga, São Paulo, Brazil.

3 Professor, PhD. Universidade Federal do Mato Grosso, Rondonópolis, Mato Grosso, Brazil.

4 Professor, PhD. Department of Food Engineering. School of Animal Science and Food Engineering. Universidade de São Paulo, Pirassununga, São Paulo, Brazil.

5 Full Professor. Department of Animal Science. School of Animal Science and Food Engineering. Universidade de São Paulo, Pirassununga, São Paulo, Brazil.

6 Professor, PhD. Department of Food Engineering. School of Animal Science and Food Engineering. Universidade de São Paulo, Pirassununga, São Paulo, Brasil.

\section{mail Adress}

Karina Márcia Ribeiro de Souza

University of São Paulo

Faculty of Animal Science and Food

Engineering

Animal Science Department.

Rua Duque de Caxias Norte, 225 - Centro

13.635-900. Pirassununga, SP, Brasil.

E-mail: karinamrs@gmail.com

\section{Eeywords}

Color, microbiology testing, sensory evaluation, soybean oil, spent layers.

\begin{abstract}
The aim of this study was to evaluate the viability of the use of spent laying hens' meat in the manufacturing of mortadella-type sausages with healthy appeal by using vegetable oil instead of animal fat. 120 Hy-line ${ }^{\circledR}$ layer hens were distributed in a completely randomized design into two treatments of six replicates with ten birds each. The treatments were birds from light Hy-line ${ }^{\circledR}$ W36 and semi-heavy Hy-line ${ }^{\circledR}$ Brown lines. Cold carcass, wing, breast and leg fillets yields were determined. Dry matter, protein, and lipid contents were determined in breast and leg fillets. The breast and legg fillets of three replicates per treatment were used to manufacture mortadella. After processing, sausages were evaluated for proximal composition, objective color, microbiological parameters, fatty acid profile and sensory acceptance. The meat of light and semi-heavy spent hens presented good yield and composition, allowing it to be used as raw material for the manufacture of processed products. Mortadellas were safe from microbiological point of view, and those made with semi-heavy hens fillets were redder and better accepted by consumers. Values for all sensory attributes were evaluated over score 5 (neither liked nor disliked). Both products presented high polyunsaturated fatty acid contents and good polyunsaturated to saturated fatty acid ratio. The excellent potential for the use of meat from spent layer hens of both varieties in the manufacturing of healthier mortadella-type sausage was demonstrated.
\end{abstract}

\section{INTRODUCTION}

According to statistics from the Brazilian Poultry Association (UBA, 2009), 60 million laying hens were housed in Brazil (white and brown eggs) in 2008. Considering that the number of birds housed corresponds to the amount of pullets introduced to replace old spent hens, then a similar number must have been culled in the same period. If the volume of biological matter, labor, and associated transportation costs are taken into account, the disposal of layer hens is one of the main economical and environmental problems of the poultry industry (Lyons, 2001). In addition, with the increase of broiler production, the sale of spent breeding hens at reasonable prices has become more difficult, affecting producers' profits (Kondaiah, 1993).Spent hens are usually slaughtered and used in feed production and concentrated stock preparations, or sold domestic consumption in soups and stews (Ajuyah et al., 1992; Voller-Reasonover et al., 1997). However, a better use of hens at the end of laying cycle, for example, in the manufacturing of food products with higher added value, could provide economic benefits for the Brazilian poultry industry.

Brazil is a developing country and a significant part of its population has limited access to fresh beef, and is only able to buy processed meat. 
Therefore, the consumption of sausages is high. Mortadella is one of the most consumed sausages in Brazil, and its consumption has increased approximately $10 \%$ per year (Barbosa et al., 2006). Thus, it might be interesting to use meat of laying hens at the end of laying cycle in sausage manufacture, since its possible hardness is not an obstacle for the production of most processed products, which use ground meat (Kondaiah \& Panda, 1992).

High consumption of saturated fatty acids increases total cholesterol and LDL cholesterol in humans. Reduced consumption of saturated fat is recommended in the treatment of hypercholesterolemia, and it was found that the replacement of saturated fatty acids by polyunsaturated fatty acids reduces total cholesterol and blood LDL (SOCESP, 2006). Meat is the major source of fat in the diet, especially of saturated fatty acids (SFA), which have been implicated in diseases associated with modern life. The ratio of $n-6: n-3$ polyunsaturated fatty acids (PUFA) is also a risk factor for different types of cancer and for coronary heart diseases, particularly for the formation of blood clots leading to heart attack (Fernández-Ginés, 2005). Vegetable oils have been used as partial substitutes of pork fat in low-fat frankfurters and other types of cooked products, their inclusion allows manufacturing food products with more adequate fatty acid profiles and cholesterol levels than traditional ones (Muguerza et al., 2001). Soybean oil is very rich in polyunsaturated fatty acids, mostly linoleic acid, whose concentration ranges from 49.8 to $57.1 \%$ (Firestone, 1999), and also present the highest PUFA percentage - around 60\% as compared to near $30 \%$ in canola oil -, and also the highest PUFA / SFA ratio (Maia et al., 2006).

The objective of this study was to evaluate, analyzing carcass yield and physical-chemical and sensory parameters, the feasibility of using the meat of light and semi-heavy spent layer hens in the manufacturing of mortadella-type sausages presenting better nutritional profile by using soybean oil instead of animal fat, which is traditionally added.

\section{MATERIAL AND METHODS}

\section{Raw materials}

One hundred and twenty laying hens at the end of the second production cycle (110 weeks old) were used, being 60 of the Hy-line ${ }^{\circledR}$ W36 (light) line and 60 of the Hy-line ${ }^{\circledR}$ Brown (semi-heavy) line. Birds were distributed in a complete randomized design into two treatments (layer genetic lines) with six replicates of ten birds each. All layers were fed the same diet since the beginning of the second production cycle. Birds were slaughtered at the experimental processing plant at USP Pirassununga campus. Birds were hung by their feet, stunned by electric shock, bled, scalded, plucked, and eviscerated. Carcasses were then washed under running water and chilled by immersion in cold water, packed in polyethylene bags, and stored in a cold-storage room at $4^{\circ} \mathrm{C}$ until the following day (approximately 20 hours), when carcasses were deboned and cut up.

\section{Carcass yield of spent laying hens}

Cold carcass, wing, breast fillet, and leg yields were determined in relation to body weight (BW) before slaughter.

\section{Processing of mortadella-type sausages}

Leg and breast fillets of three replicates per treatment were used to manufacture the sausages, in a total of two $15-\mathrm{kg}$ batches per treatment. Sausage formula is shown in Table 1 and was used in the manufacture of both products obtained, which differed only as to raw meat source (breast and leg fillets from light or semi-heavy spent laying hens). Soybean oil was mixed with the meat and other ingredients in a rotary bowl homogenizer (cutter) for about 10 minutes. Meat emulsions were removed from the cutter at temperatures below $14^{\circ} \mathrm{C}$, and were stuffed in fibrous cellulose casings. Sausages were cooked in an oven until internal temperature reached $75^{\circ} \mathrm{C}$. After cooking, the mortadella-type sausages were cooled under cold water shower and whole pieces were vacuum-packed and stored at $0^{\circ} \mathrm{C}\left( \pm 1^{\circ} \mathrm{C}\right)$, in the absence of light, until analysis.

\begin{tabular}{|l|c|c|}
\hline \multicolumn{3}{|l|}{ Table 1 - Formula used to manufacture mortadellas. } \\
\hline Ingredients & Percentage(\%) & Weight (kg) \\
\hline Breast fillet & 24.00 & 3.600 \\
\hline Leg fillet & 36.00 & 5.400 \\
\hline Soybean oil & 15.00 & 2.250 \\
\hline Ice & 16.15 & 2.420 \\
\hline Salt & 0.80 & 0.120 \\
\hline Curing salt & 0.30 & 0.045 \\
\hline Antioxidant & 0.25 & 0.038 \\
\hline Emulsifier & 0.50 & 0.075 \\
\hline Condiment for chicken sausage & 1.00 & 0.150 \\
\hline Cassava starch & 5.00 & 0.750 \\
\hline Garlic & 0.50 & 0.075 \\
\hline Flavor enhancer & 0.40 & 0.060 \\
\hline White pepper & 0.10 & 0.015 \\
\hline TOTAL & 100.00 & 15.000 \\
\hline
\end{tabular}




\section{Calculation of mortadellas process yield}

In order to calculate process yield, the sausages were weighed before entering the oven and immediately after cooking/cooling. Yield was calculated using the following equation:

\section{Yield $(\%)=($ final weight $/$ initial weight $) \times 100$}

\section{Proximate composition}

The proximate composition of the raw material (breast and leg fillets) and of the finished product (mortadella-type sausages) was determined in triplicate, according to AOAC methodology (Cunnif, 1998). Protein content was determined by the microKjeldahl method; fat was extracted in a Soxhlet extractor; moisture was evaluated by gravimetry and the ash content was determined by incineration in a muffle furnace.

\section{Microbiological evaluation of the finished product}

Previously to sensory evaluation, all treatments were analyzed for the presence of Salmonella and coliform count at $45^{\circ}$, positive coagulase Staphylococcus count, and sulfite-reducing clostridia count. Microbial analyses were carried out according to the methodology described by Vanderzant and Splittstoesser (1992).

\section{Objective color determination in the finished product}

The $L$ * (lightness), $a$ * (redness) and $b$ * (yellowness) values were determined using a portable colorimeter (Miniscan XE), operating with D65 light source, $10^{\circ}$ angle view, and $30 \mathrm{~mm}$ cell opening.

\section{Fatty acid profile of the finished product}

The lipid fraction of the sausages, extracted according to methodology suggested by Folch et al. (1957), was analyzed by gas chromatography of fatty acids methyl esters in accordance with official method (Ce 1-62 (97), AOCS 1998). Before chromatographic analysis, the lipid fractions were prepared in the form of fatty acids methyl esters using AOCS methodology (Ce 2-66 (97), AOCS 1998). A Shimadzu 2010 AF (Japan) gas chromatograph, equipped with an automatic injector (Shimadzu, model AOC 20i, Japan) and flame ionization detector, was used under the following experimental conditions: capillary column Crossbond-PEG $0.25 \mathrm{~m}, 30 \mathrm{~m} \times 0.25 \mathrm{~mm}$ id. (RTX-Wax, Restek, Bellefonte, PA, USA), helium carrier gas at a rate of $0.74 \mathrm{~mL} / \mathrm{min}$, injector temperature of $250^{\circ} \mathrm{C}$, and column temperature of $(160-245)^{\circ} \mathrm{C}\left(3^{\circ} \mathrm{C} / \mathrm{min}\right.$ rate), temperature detector of $280^{\circ} \mathrm{C}$. The fatty acids methyl esters were identified by comparison with retention times of Supelco standards (Bellefonte, PA, USA) and quantification was performed by internal standardization.

\section{Sensory evaluation of the finished products}

The sensory evaluation of the produced sausages used affective acceptance tests that were performed to assess the acceptance degree perceived by consumers of both types of products (containing meat of light or semi-heavy hens). The team consisted of 80 consumers, including students, professors, and staff of the School of Animal Science and Food Engineering (FZEA-USP) recruited based on their affinity for the product. Two replicates per treatment were evaluated. All consumers read and signed the Clear and Free Consent Form. Samples were sliced to $1.5 \mathrm{~mm}$ thickness, and two slices of each sample were monadically and randomly offered on plastic plates and a fork. Consumers were asked to evaluate the samples using a nine-point verbal hedonic scale $(1=$ extremely disliked to $9=$ extremely liked) with regard to color, aroma (which should be evaluated by raising one of the slices and feeling the smell between them), flavor, texture, and overall quality.

\section{Statistical analyses}

Data on body weight, carcass, wing, breast and leg fillet yields, and objective color were submitted to analysis of variance, and means were compared by the $F$ test. Consumer acceptance data were analyzed by ANOVA, using a mixed model, considering panelist as random effect and treatment as fixed effect. Significance was defined at $p \leq 0.05$ for all parameters. SAS $^{\circledast}\left({ }^{\circledR} 2000\right.$, SAS Inst. Inc.) software package was used for the statistical analyses.

\section{RESULTS AND DISCUSSION}

Carcass yield and proximate composition of the meat obtained from light and semi-heavy spent laying hens

Semi-heavy hens had higher BW and breast, leg and wing yields $(p<0.05)$, but there were no significant differences in cold carcass yield between genetic lines (Table 2). Meat yield depends on bird age and weight, with heavier laying hens presenting higher yields and better quality products than light hens (Kondaiah \& Panda, 1992). Nardin et al. (1999) obtained 14.73\% 
breast fillet yield with light hens (white meat); however, the value obtained was determined relative to carcass weight, which was, in average, $1.20 \mathrm{~kg}$ in that study.

Table 2 - Body weight, carcass, and fillet yields of laying hens at the end of the second laying cycle.

\begin{tabular}{|l|c|c|c|}
\hline \multirow{2}{*}{ Variables $^{1}$} & \multicolumn{2}{|c|}{ Laying hen } & \multirow{2}{*}{ CV$^{2}$ (\%) } \\
\cline { 2 - 3 } & Light & Semi-heavy & \\
\hline BW (kg) & $1.61^{\mathrm{b}}$ & $2.06^{\mathrm{a}}$ & 2.53 \\
\hline CY (\%) & 62.09 & 63.18 & 3.95 \\
\hline BFY (\%) & $9.68^{\mathrm{b}}$ & $10.40^{\mathrm{a}}$ & 5.65 \\
\hline LFY (\%) & $12.29^{\mathrm{b}}$ & $13.38^{\mathrm{a}}$ & 3.91 \\
\hline WY (\%) & $6.56^{\mathrm{b}}$ & $7.28^{\mathrm{a}}$ & 4.34 \\
\hline
\end{tabular}

1 - BW: Body Weight; CY: Carcass Yield; BFY: Breast Fillet Yield; LFY: Leg Fillet Yield; WY: Wing Yield. 2 - CV: Coefficient of Variation.

The proximate compositions of breast and legs fillets and of the finished products are shown in Table 3. The composition of breast and leg fillets was similar to that reported in literature (Kondaiah \& Panda, 1992). On the other hand, Nardin et al. (1999) found lower CP and $\mathrm{EE}$ values (19.60\% and $3.75 \%$, respectively) in the mixed meat (breast, legs, thighs and drummettes) of light hens as compared to those obtained in the present study. Information on physical-chemical properties of the meat of spent hens is essential for the development of processed products, since they determine the quality of final products (Kondaiah \& Panda, 1992).

\begin{tabular}{|c|c|c|c|c|}
\hline \multirow{3}{*}{ Constituents $^{1}$} & \multicolumn{4}{|c|}{ Laying hens } \\
\hline & \multicolumn{2}{|c|}{ Light } & \multicolumn{2}{|c|}{ Semi-heavy } \\
\hline & $\mathrm{BF}^{3}$ & $\mathrm{LF}^{3}$ & BF & LF \\
\hline $\mathrm{HU}(\%)$ & 69.62 & 66.73 & 71.49 & 68.06 \\
\hline DM (\%) & 30.38 & 33.27 & 28.51 & 31.92 \\
\hline$C P^{2}(\%)$ & 22.52 & 19.69 & 23.79 & 19.02 \\
\hline \multirow[t]{3}{*}{$\mathrm{EE}^{2}(\%)$} & 5.78 & 11.99 & 1.84 & 10.97 \\
\hline & \multicolumn{4}{|c|}{ Mortadellas } \\
\hline & \multicolumn{2}{|c|}{ Light } & \multicolumn{2}{|c|}{ Semi-heavy } \\
\hline $\mathrm{HU}(\%)$ & \multicolumn{2}{|c|}{53.88} & \multicolumn{2}{|c|}{53.41} \\
\hline DM (\%) & \multicolumn{2}{|c|}{46.12} & \multicolumn{2}{|c|}{46.59} \\
\hline$C P^{2}(\%)$ & \multicolumn{2}{|c|}{13.56} & \multicolumn{2}{|c|}{13.54} \\
\hline $\mathrm{EE}^{2}(\%)$ & \multicolumn{2}{|c|}{19.29} & \multicolumn{2}{|c|}{19.56} \\
\hline $\operatorname{AS}^{2}(\%)$ & \multicolumn{2}{|c|}{3.16} & \multicolumn{2}{|c|}{3.29} \\
\hline
\end{tabular}

\section{Characterization of mortadellas including spent laying hen meat and vegetable oil}

The proximate composition results of mortadellas (Table 3) are consistent with the Standards of Identity and Quality of Mortadella-type Sausages (Brasil, 2000), which establish limits of up to $30 \%$ fat, $65 \%$ humidity, and a minimum of $12 \%$ protein. $\mathrm{HU}$ and $\mathrm{CP}$ values of mortadella using the meat of spent laying hens were similar to those reported by Jin et al. (2007) for mortadella made with $0,20,40$, or $60 \%$ of spent laying hen surimi, but they obtained lower EE values as compared to the present study.

The results of the microbiological tests did not show the presence of Salmonella $\mathrm{sp}$ in any of the treatments. Moreover, coliforms at $45^{\circ} \mathrm{C}(<3 \mathrm{MPN} / \mathrm{g})$, positive coagulase Staphylococcus $\left(<1 \times 10^{1} \quad \mathrm{CFU} / \mathrm{g}\right)$ and sulfite-reducing clostridia ( $<1 \times 10^{1} \mathrm{CFU} / \mathrm{g}$ counts complied to the standard established by the Brazilian legislation (Brasil, 2001).

Objective color analysis showed the sausages that contained semi-heavy chicken fillets were more reddish, as evidenced by the higher $a^{*}$ value in the CIEL* $a * b *$ scale system (Table 4). However, in general, the use of chicken fillets and the absence of pigments in the formulation resulted in products with low a*values that presented a light pink color. Trindade et al. (2005) reported that increasing the percentage of mechanically-deboned hen meat in the formulation of sausages had negative effect on $a^{*}$ values, resulting in products with less intense red color.

Table 4 - Color of mortadella sausages prepared with breast and leg fillets from hens at the end of the second production cycle ${ }^{1}$.

\begin{tabular}{l|c|c|c|}
\hline Genetic line & $\mathbf{L}^{*}$ & $\mathbf{a}^{*}$ & $\mathbf{b}^{*}$ \\
\hline Light & 80.20 & $5.26 \mathrm{~b}$ & 13.59 \\
\hline Semi-heavy & 79.81 & $5.67 a$ & 13.57 \\
\hline $\mathrm{CV}(\%)$ & 0.74 & 3.86 & 2.01 \\
\hline $\begin{array}{l}\text { 1 - Means followed by different letters in the same column are statistically } \\
\text { different ( } p<0.05) \text { by F test. }\end{array}$
\end{tabular}

The results of the sensory acceptance test are presented in Table 5. Sausages prepared with semiheavy layer meat were better accepted in terms of texture and overall quality attributes, but did not differ from sausages made of light layer meat in relation to the other attributes. It was observed that all values of the evaluated attributes were above the acceptance limit for the product (score 5, which indicates "neither liked nor disliked"). Trindade et al. (2005) found that, the overall product quality decreased with the increase of spent hen meat percentage in the formulation of sausages; however, the values for this attribute remained above the acceptance level 5 . 
Souza KMR de, Araujo RB, Santos AL dos, Rodrigues CEC, Faria DE de, Trindade MA
Adding Value to the Meat of Spent Laying Hens Manufacturing Sausages with a Healthy Appeal
The fatty acid (FA) profile of mortadella sausages made of light and semi-heavy spent hen meat is shown in Table 6 . The results show that the fatty acid profile of both products was very similar, which was expected, since the main fat source was soybean oil in both treatments, with the addition of $15 \%$ in the formulation of sausages, and also because hens were fed similar diets in terms of FA profile.

Table 5 - Means of the sensory attributes of mortadella sausages prepared with breast and legs fillets of hens at the end of the second production cycle ${ }^{1}$.

\begin{tabular}{|c|c|c|}
\hline Characteristics & Light & Semi-heavy \\
\hline Color & 5.95 & 6.36 \\
\hline Aroma & 6.40 & 6.76 \\
\hline Flavor & 6.08 & 6.52 \\
\hline Texture & $5.52 b$ & $6.22 a$ \\
\hline Overall quality & $5.90 \mathrm{~b}$ & $6.50 a$ \\
\hline \multicolumn{3}{|c|}{$\begin{array}{l}1 \text { - Means followed by different letters in row differ statistically }(p<0.05 \\
\text { by } F \text { test. }\end{array}$} \\
\hline
\end{tabular}

According to data presented in Table 6, it was observed that the main fatty acid present in triacylglycerols that make up the lipid fraction of sausages obtained from light and semi-heavy chicken was linoleic acid, followed by oleic acid. In fact, the fatty acid composition of sausages of the treatments used in the present experiment differs from sausages made of standard chicken meat and traditional sausages, which lipid fraction derives from beef and pork fat). This difference in composition is shown in Table 6, according to data from Baggio \& Bragagnolo (2006) and Baggio \& Bragagnolo (2008).

The high polyunsaturated fatty acid content of the sausages of the present study presents 4.4 to 5.5 times higher PUFA/SFA ratio than those obtained in commercial sausages, and the values can be compared to the range present in soybean oil (Table 6).

The World Health Organization (WHO, 2010) recommends a daily intake of saturated fatty acids below $10 \%$ for healthy individuals and less than $7 \%$ for individuals in the risk group for cardiovascular diseases.

Table $\mathbf{6}$ - Comparison of the fatty acid profile of mortadella sausages prepared with breast and leg fillets of laying hens at the end of the second production cycle and of other products.

\begin{tabular}{|c|c|c|c|c|c|}
\hline Fatty acid & $\begin{array}{l}\text { Light } \\
(\%)\end{array}$ & $\begin{array}{l}\text { Semi-heavy (\%) } \\
M \pm S D\end{array}$ & $\begin{array}{l}\text { Chicken mortadella }{ }^{a}(\%) \\
M \pm S D\end{array}$ & $\begin{array}{l}\text { Traditional mortadellab }(\%) \\
\qquad M \pm S D\end{array}$ & $\begin{array}{c}\text { Soybean oil } \\
(\%)\end{array}$ \\
\hline C12:0 & & & & & $0-0.1$ \\
\hline C14:0 & $0.2 \pm 0.0$ & $0.2 \pm 0.0$ & $0.8 \pm 0.0$ & $1.0 \pm 0.1$ & $0-0.2$ \\
\hline C15:0 & & $0.1 \pm 0.0$ & $0.2 \pm 0.1$ & $0.2 \pm 0.0$ & \\
\hline C16:0 & $12.9 \pm 0.1$ & $12.5 \pm 0.1$ & $24.1 \pm 0.7$ & $24.3 \pm 0.8$ & $9.7-13.3$ \\
\hline C17:0 & $0.1 \pm 0.0$ & $0.1 \pm 0.0$ & $0.3 \pm 0.0$ & $0.3 \pm 0.0$ & \\
\hline C18:0 & $3.4 \pm 0.1$ & $3.6 \pm 0.0$ & $7.0 \pm 0.2$ & $9.3 \pm 0.7$ & $3.0-5.4$ \\
\hline$C 20: 0$ & $0.2 \pm 0.0$ & $0.3 \pm 0.0$ & $0.1 \pm 0.0$ & $0.1 \pm 0.0$ & $0.1-0.6$ \\
\hline$C 22: 0$ & & & $0.1 \pm 0.0$ & & $0.3-0.7$ \\
\hline C24:0 & $0.1 \pm 0.0$ & $0.1 \pm 0.0$ & $0.1 \pm 0.0$ & $0.2 \pm 0.1$ & $0-0.4$ \\
\hline C16:1 & $0.9 \pm 0.1$ & $0.6 \pm 0.0$ & $4.6 \pm 0.1$ & $3.5 \pm 0.4$ & $0-0.2$ \\
\hline C17:1 & & & $0.3 \pm 0.1$ & $0.3 \pm 0.0$ & \\
\hline C18:1 & $29.5 \pm 0.4$ & $27.8 \pm 0.1$ & $39.5 \pm 0.9$ & $40.3 \pm 0.3$ & $17.7-28.5$ \\
\hline$C 20: 1$ & $0.2 \pm 0.0$ & $0.2 \pm 0.0$ & $0.4 \pm 0.1$ & $0.5 \pm 0.1$ & $0-0.3$ \\
\hline$C 22: 1$ & $0.1 \pm 0.0$ & $0.1 \pm 0.0$ & & & $0-0.3$ \\
\hline C18:2 & $47.5 \pm 0.5$ & $49.3 \pm 0.2$ & $20.7 \pm 0.3$ & $18.8 \pm 0.9$ & $49.8-57.1$ \\
\hline C18:3 & $4.4 \pm 0.1$ & $4.7 \pm 0.0$ & $1.3 \pm 0.2$ & $1.1 \pm 0.0$ & $5.5-9.5$ \\
\hline$C 20: 2$ & & & $0.2 \pm 0.0$ & $0.3 \pm 0.1$ & $0-0.1$ \\
\hline$C 20: 3$ & $0.2 \pm 0.0$ & $0.3 \pm 0.0$ & & & \\
\hline$C 20: 4$ & & & $0.4 \pm 0.0$ & $0.3 \pm 0.1$ & \\
\hline$C 20: 5$ & $0.3 \pm 0.0$ & $0.3 \pm 0.0$ & & & \\
\hline SFA & 16.9 & 16.8 & 32.5 & 35.4 & $13.1-20.7$ \\
\hline MUFA & 30.7 & 28.7 & 44.8 & 44.6 & $17.7-29.0$ \\
\hline PUFA & 52.4 & 54.6 & 22.6 & 20.5 & $55.3-66.7$ \\
\hline PUFA/SFA & 3.1 & 3.3 & 0.7 & 0.6 & $3.2-4.2$ \\
\hline
\end{tabular}


The daily intake recommendation of polyunsaturated fatty acids is $6-10 \%$ of total dietary fat. Therefore, it could be inferred that PUFA/SFA ratios higher than 1 are highly recommended to maintain a balanced diet. In the present study, PUFA/SFA ratios of 3 were obtained for both sausages, that is, the addition of soybean oil allowed the production of sausages with strong healthy appeal.

In relation to the type of saturated fatty acid, the WHO (2010) emphasizes that saturated fatty acids with 12-16 carbon atoms in the carbon chain must be avoided due to their high potential to increase LDL cholesterol. According to the data presented in Table 6 , the addition of soybean oil to sausages allowed the reduction of palmitic acid content in half, which reinforces the previous comments.

\section{CONCLUSION}

In general, the manufacture of mortadella-type sausages with vegetable oil shows good potential for the utilization of meat of light and semi-heavy spent laying hens. The obtained products, despite the undesirable light color, are safe, from microbiological point of view, and have good nutritional value. Furthermore, the sensory acceptability of color can be enhanced by adding natural pigments.

\section{REFERENCES}

Ajuyah AO, Hardin TR, Cheung K, Sim JS. Yield, lipid, cholesterol and fatty acid composition of spent hens fed full-fat oil seeds and fish meal diets. Journal of Food Science 1992; 57(2):338-341.

AOCS. Official methods and recommended practices of the american oil chemists' society. Champaign: AOCS Press; 1998.

Barbosa LN, Garcia LV, Tolotti LD, Goellner T, Augusto-Ruiz W, Espírito santo MLP. Elaboração de embutido tipo mortadela com farelo de arroz. Vetor - Revista de Ciências Exatas e Engenharias 2006; 16(1/2):11-20.

Baggio SR, Bragagnolo N. Fatty acids, cholesterol oxides and cholesterol in brazilian processed chicken products. Italian Journal of Food Science 2006; 18(2):199-208.

Baggio SR, Bragagnolo N. Lipid fraction quality evaluation of brazilian meat-based products. Journal of Brazilian Chemistry Society. 2008; 19(3):463-470.

Brasil. Leis, Decretos etc. Instrução Normativa nº 4, de 31 de março de 2000 da Secretaria de Defesa Agropecuária do Ministério da Agricultura e do Abastecimento. Aprova os Regulamentos Técnicos de Identidade e Qualidade de Carne Mecanicamente Separada, de Mortadela, de Linguiça e de Salsicha. Diário Oficial da Republica Federativa do Brasil, Brasília, DF, 05 abr. 2000, Seção 1, p.6-10.
Brasil. Leis, Decretos etc. Resolução RDC $n^{\circ} 12$ de 2 de Janeiro de 2001 [cited 2009 Jan 20]. Available from: http://www.anvisa.gov. br/legis/resol/ 12_01rdc.htm.

Cunnif P. Official methods of analysis of AOAC International. 16th ed Arlington; 1998. Chapter 16, p.26-27.

Firestone D. Physical and Chemical Characteristics of oils, fats, and Waxes. Washington, D.C: AOCS Press; 1999.

Jin SK, Kim Sl, Jung HJ, Kim DH, Choi YJ, Hur SJ. The development of sausage including meat from spent laying hen surimi. Poultry Science 2007; 86:2676-2684.

Kondaiah N, Panda B. World's Poultry Science Journal 1992; 48:255-268

Kondaiah N. Products from spent hen. Poultry In tternational 1993; 49(1):46-47.

Fernández-Ginés JM, Fernández-López J, Sayas-Barberá E, PérezAlvarez JA. Meat products as functional foods: A review. Journal Food Science 2005; 70(2):37-43.

Folch J, Lees M, Stanley GHS. A simple method for the isolation and purification of total lipides from animal tissues. Journal of Biological Chemistry 1957; 22:497-509.

Lyons JJ. Spent hen utilization. III Midwest Poultry Federation Egg Production Workshop; 2001; St. Paul, Minn. Mt. Morris, U.S.A: Watt Publsihing [cited 2005 Mar 18]. Available from: http://www. wattnet.com/library/download3D7sphened.pdf.

Maia FJ, Branco AF, Mouro GF, Coneglian SM, Santos GT, Minella TF, Guimarães KC. Inclusão de fontes de óleo na dieta de cabras em lactação: produção, composição e perfil dos ácidos graxos do leite. Revista Brasileira de Zootecnia 2006; 35:1504-1513.

Muguerza E, Gimeno O, Ansorena D, Bloukas JG, Astiasarán I. Effect of replacing pork backfat with pre-emulsified olive oil on lipid fraction and sensory quality of chorizo de pamplona: a traditional spanish fermented sausage. Meat Science 2001; 59:251-258.

Nardin TRF, Graner M, Verruma-Bernardi MR. Produtos de emulsão (fiambres) elaborados com carne de poedeiras leves (leghorn) de descarte e óleos vegetais. Scientia Agricola 1999; 56(2):363-370.

SOCESP. Sociedade de Cardiologia do Estado de São Paulo. Os diferentes tipos de gordura no sangue [citado 2006 Nov 20]. Disponível em: http://www.socesp.org.br/espaco_leigo/colesterol_ fator_risco.asp.

Trindade MA, Contreras CJC, Felício PE. Mortadella sausage formulations with partial and total replacement of beef and pork backfat with mechanically separated meat from spent layer hens. Journal of Food Science 2005; 70:236-241.

WHO - World Health Organization. Population nutrient intake goals for preventing diet-related chronic diseases. 2010 [cited 2010 Abr 23]. Available at: http://www.who.int/nutrition/topics/5_ population_nutrient/en/print.html.

UBA - União Brasileira de Avicultura. Levantamento do alojamento 
de matrizes e comerciais. Relatório Anual 2008.

Vanderzant C, Splittstoesser DF. Compendium of methods for the microbiological examination of foods. 3rd ed Washington, DC: American Public Health Association; 1992.

Voller-Reasonover L, Han IY, Acton JC, Titus TC, Bridges WC, Dawson PL. High Temperature processing effects on the properties of fowl meat gels. Poultry Science 1997; 76:774-779. 

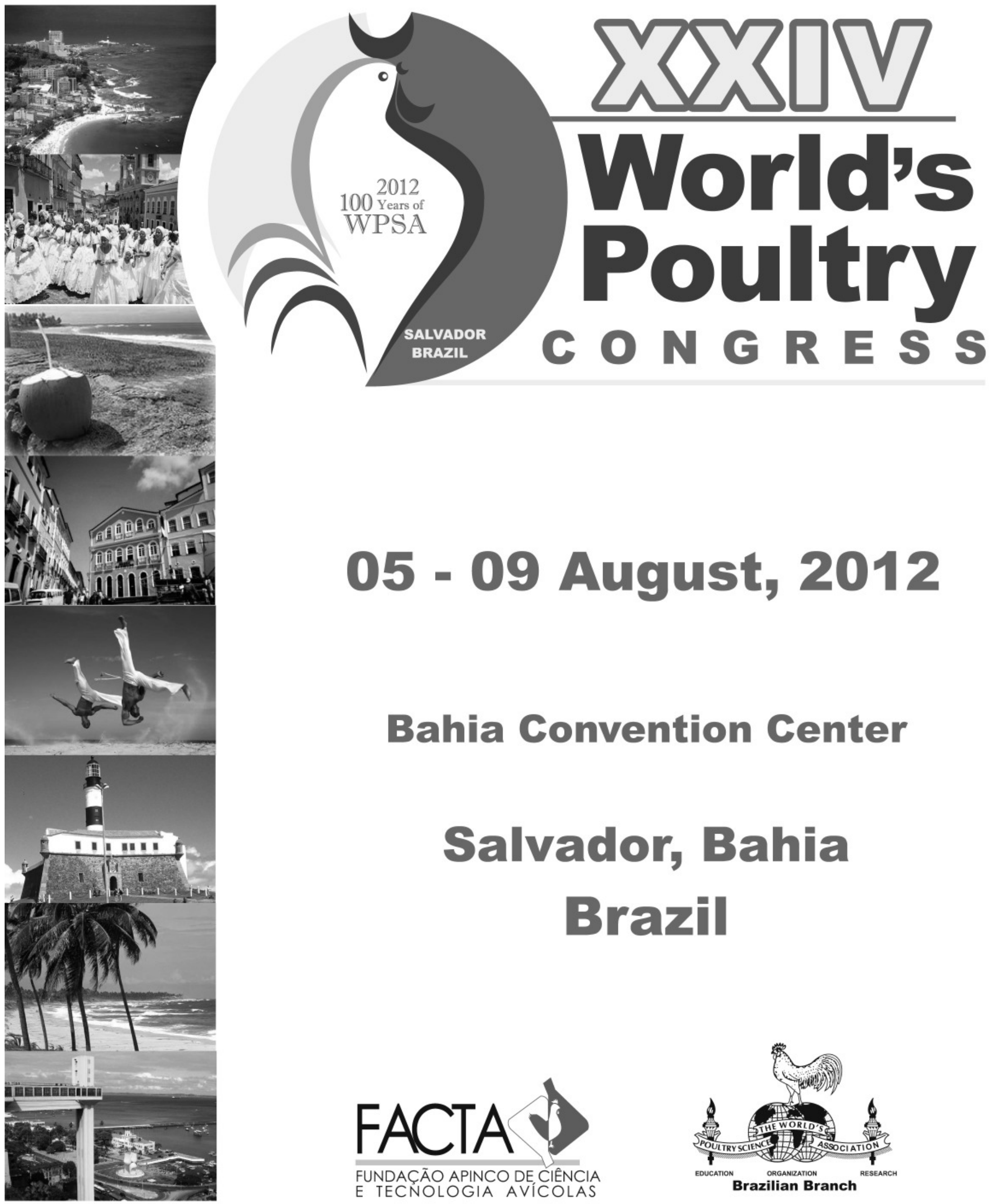

05 - 09 August, 2012

Bahia Convention Center

Salvador, Bahia

Brazil
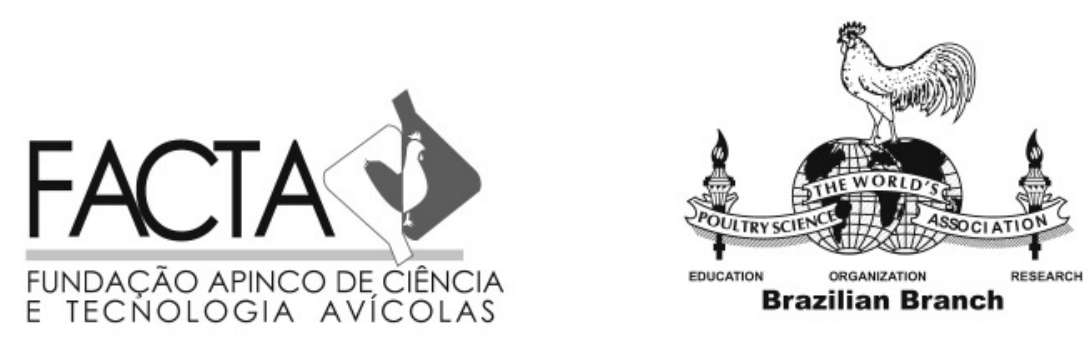